by Arthur H. Hickman ${ }^{l}$ and Martin J. Van Kranendonk ${ }^{2}$

\title{
Early Earth evolution: evidence from the 3.5-1.8 Ga geological history of the Pilbara region of Western Australia
}

\author{
${ }^{1}$ Geological Survey of Western Australia, 100 Plain St., East Perth, WA 6004, Australia. E-mail: arthur.hickman@dmp.wa.gov.au \\ ${ }^{2}$ School of Biology, Earth and Environment, University of New South Wales, Randwick, NSW 2052, Australia. E-mail: \\ martin.vankranendonk@unsw.edu.au
}

The Pilbara region of Western Australia is one of only two areas on Earth - the other being the Kaapvaal Craton of southern Africa - that contain well preserved, nearcontinuous geological records of crustal evolution from the Paleoarchean into the late Paleoproterozoic. The Pilbara is famous for hosting fossil evidence of early life (stromatolites and microfossils), and for containing a record of the early Archean atmosphere. The geological record extends from granite-greenstone terranes and overlying clastic basins of the 3.53-2.83 Ga Pilbara Craton, across a major unconformity, to a series of 2.78 $1.79 \mathrm{Ga}$ volcanic and sedimentary successions. Between 3.53-3.23 Ga, a succession of mantle plume events formed a thick volcanic plateau on older continental crust, remnants of which include enclaves of c. $3.6 \mathrm{Ga}$ granitic gneiss and abundant 3.8-3.6 Ga inherited and detrital zircons. During each of the plume events, the volcanic plateau was intruded by crustally-derived granitic rocks, leading to vertical deformation by partial convective overturn. By $3.23 \mathrm{Ga}$, these processes had established thick continental crust that was then rifted into three microplates separated by c. $3.2 \mathrm{Ga}$ basins of oceanic crust. Subsequent plate tectonic processes to 2.90 Ga included subduction, terrane accretion, and orogeny. From 2.78-2.63 Ga the northern Pilbara Craton was affected by minor rifting, followed by deposition of thick basaltic formations separated by felsic volcanic and sedimentary rocks (Fortescue Basin). Rifting in the southern Pilbara resulted in progressively deepening marginal basin sedimentation, including thick units of banded iron formation (Hamersley Basin: 2.63-2.45 Ga). At c. $2.45 \mathrm{Ga}$, sedimentation in the southern Pilbara changed to a mixed assemblage of clastic and carbonate sedimentary rocks of the Turee Creek Basin, including one unit of glacial diamictites. Deposition of the unconformably overlying 2.21-1.79 Ga Wyloo Group in the Ashburton Basin followed the Ophthalmian Orogeny, and all of these rocks were deformed by the Panhandle (c. 2 Ga) and Capricorn (c. 1.78 Ga) orogenies.

\section{Introduction}

The Pilbara region of Western Australia is one of only two areas in the world - the other being the Kaapvaal Craton of southern Africa - that provides extensive exposures of well preserved Paleoarcheanlate Paleoproterozoic crust from which extensive information about the evolution of crustal processes, the biosphere and atmosphere has been obtained. The Pilbara contains three major ArcheanPaleoproterozoic tectonic divisions: (1), the Pilbara Craton, composed of early crust (3.80-3.53 Ga), granite-greenstone terranes (3.53-3.07 $\mathrm{Ga})$, volcanosedimentary basins $(3.05-2.93 \mathrm{Ga})$, and post-orogenic granites (2.89-2.83 Ga); (2), the Fortescue, Hamersley, and Turee Creek basins (2.78-2.42 Ga), composed of a thick succession of interbedded clastic and chemical sedimentary rocks and volcanic rocks; and (3), the Ashburton Basin (2.21-1.79 Ga), composed of the volcano-sedimentary Wyloo Group.

From 1990 until 2007, the first two of these divisions were combined as the 'Pilbara Craton' (Trendall, 1990) on the grounds that there had been a continuum of depositional and igneous events from Paleo- to Mesoarchean granite-greenstones (prior to 1990 referred to as the 'Pilbara Block' in the N Pilbara) to the Proterozoic Turee Creek Group. Accordingly, it was considered that 'tectonic stability' (defining establishment of a craton) had not been attained until $2.4 \mathrm{Ga}$. However, a major geological mapping project, conducted jointly by the Geological Survey of Western Australia and Geoscience Australia between 1995 and 2002 (Huston et al., 2002a), provided a much improved geological understanding of the craton (Van Kranendonk et al., 2002, 2007a; Huston et al., 2002b). Van Kranendonk et al. (2006) revised the lithostratigraphy and tectonic units of the Paleoarchean and Mesoarchean rocks, and used the name 'Pilbara Craton' to encompass only units older than the Fortescue Group (the lowermost stratigraphic group of the Hamersley Basin). Hickman et al. (2006) explained that the change had been made because the last major deformation event to affect the granitegreenstones of the craton occurred at $2.90 \mathrm{Ga}$, after which there had been a c. $130 \mathrm{Myr}$ period of crustal stability (apart from the intrusion of post-orogenic granites). In 2006, the Fortescue, Hamersley, and 
Turee Creek groups of the Mount Bruce Supergroup were still included within the 'Hamersley Basin', but Tyler and Hocking (2008) ascribed the succession to the Fortescue, Hamersley, and Turee Creek Basins (see also Hickman et al., 2010). The status of the Ashburton Basin has not changed since it was described by Thorne and Seymour (1991).

\section{Pilbara Craton}

Regional gravity and magnetic data indicate that the Pilbara Craton underlies $250,000 \mathrm{~km}^{2}$ of the Pilbara region (Hickman, 2004), but apart from a $60,000 \mathrm{~km}^{2}$ area in the northern Pilbara, it is largely concealed by unconformably overlying Neoarchean-Paleoproterozoic rocks of the Fortescue, Hamersley and Turee Creek basins (Figure 1). The tectonic subdivision of the northern Pilbara Craton was established by Van Kranendonk et al. (2006), and revised by Hickman et al. (2010).

\section{Overview of tectonic evolution}

The oldest part of the Pilbara Craton is 3.80-3.53 Ga crust, which has been identified by geochronology in rare outcrops of gneissic granite and gabbroic anorthosite. Geochemical and geochronological evidence shows that the early crust was present and widely exposed throughout the evolution of the craton.

Between 3.53-3.23 Ga, mantle plume activity resulted in the deposition of at least eight successive volcanic cycles on the early crust. The resulting volcanic plateau is now exceptionally well preserved as the 15-20 km-thick Pilbara Supergroup. Large volumes of granitic magma were intruded during the same period, and thick

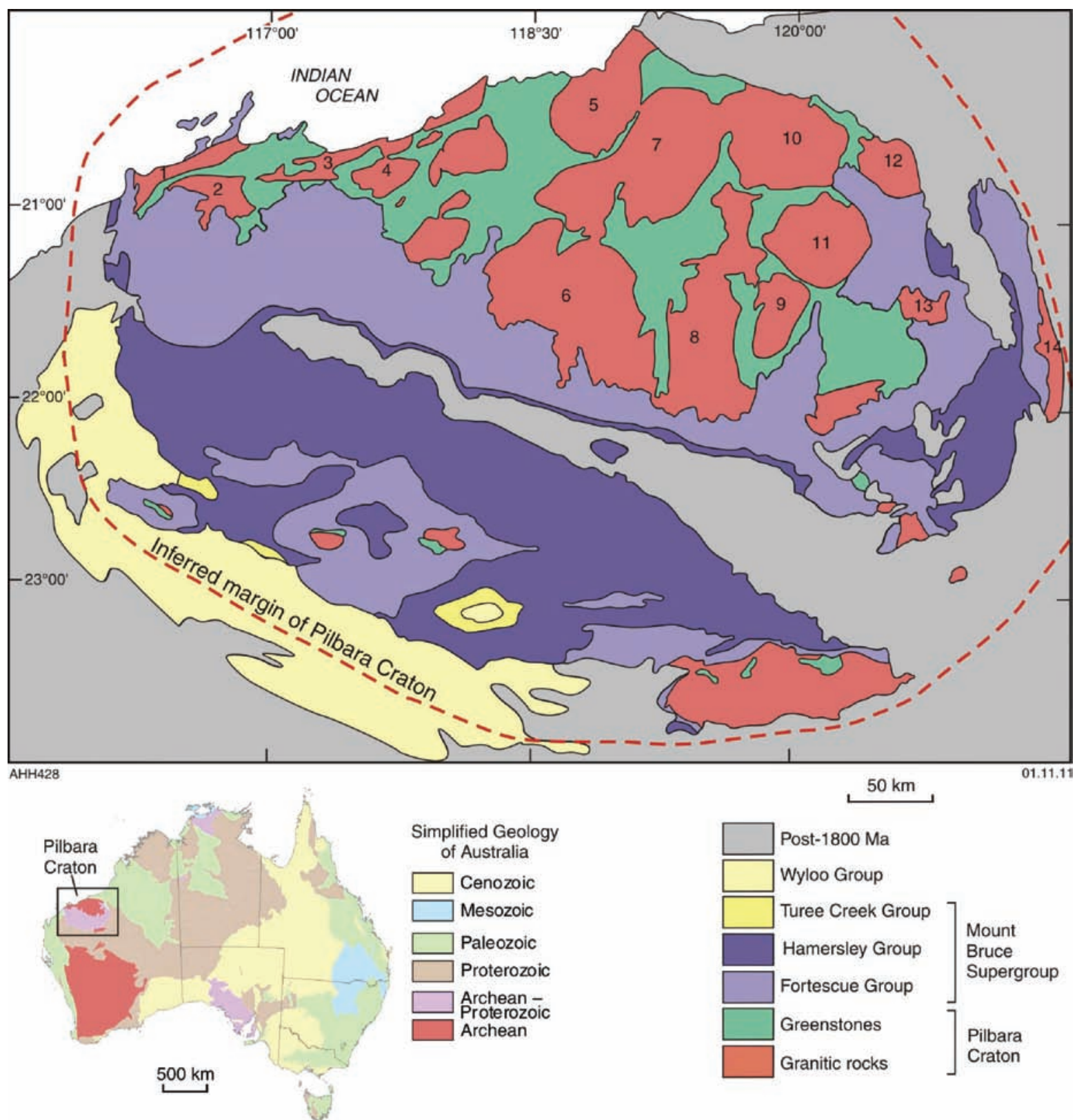

Figure 1 Simplified geology of the Pilbara region of Western Australia, showing the interpreted margin of the Pilbara Craton beneath younger rocks. Granitic complexes: 1, Dampier; 2, Cherratta; 3, Harding; 4, Caines Well; 5, Pippingarra; 6; Yule; 7, Carlindi; 8, Shaw;9, Corunna Downs; 10, Muccan; 11, Mount Edgar; 12, Warrawagine; 13, Yilgalong; 14; Gregory (after Thorne and Trendall, 2001). 
continental crust had been established by $3.23 \mathrm{Ga}$. A major rifting event between 3.23-3.16 Ga split this crust into three continental microplates (Karratha, East Pilbara and Kurrana terranes; Figure 2) separated by two NE-trending basins of oceanic crust. Early in the rifting stage, clastic deposition on the edges of the microplates formed passive margin successions, including that of the Soanesville Basin, which is the best preserved representative and unconformably overlies the northwestern side of the East Pilbara Terrane. Later in the rifting, thick successions of pillow basalt and komatiitic basalt were erupted, and the underlying crust was intruded by ultramafic and mafic dykes and sills of the $3.18 \mathrm{Ga}$ Dalton Suite.

Between 3.16-3.07 Ga, plate convergence caused part of the oceanic crust of the northwest basin to be obducted across the Karratha Terrane, establishing the Regal Terrane. Further SE, a subduction zone and intra-oceanic arc (Sholl Terrane; Figure 2) existed between 3.13-3.11 Ga. At 3.07 Ga, the NW-SE convergence responsible for the formation of the Sholl and Regal terranes culminated in the accretion of the Karratha, Sholl and Regal terranes to form the West Pilbara Superterrane. At the same time, collision of this superterrane with the East Pilbara Terrane resulted in major deformation and widespread granitic intrusion of the Prinsep Orogeny.

Crustal relaxation, extension, and moderate subsidence followed the Prinsep Orogeny and led to the development of the 3.05-2.93 Ga De Grey Superbasin across most of the northern Pilbara Craton. The De Grey Superbasin unconformably overlies the East Pilbara Terrane and the West Pilbara Superterrane. In the W Pilbara it is composed of three unconformity-bound basins: the basal 3.05-3.02 Ga Gorge Creek Basin (banded iron formation and clastic sediments); the 3.012.99 Ga Whim Creek Basin (volcanics); and the 2.97-2.94 Ga Mallina Basin (sandstone, wacke, and shale). The Mallina Basin records a history of alternating extension and compression during which there were periods of sedimentation, volcanism, and both felsic and mafic magmatic intrusion. In the SE Pilbara, the 2.98$2.93 \mathrm{Ga}$ Mosquito Creek Basin is lithologically similar to the Mallina Basin but does not contain contemporaneous igneous rocks. Deposition in both basins was terminated by major deformation (North Pilbara and Mosquito Creek orogenies) between 2.94$2.90 \mathrm{Ga}$. Except for post-orogenic intrusion of highly fractionated

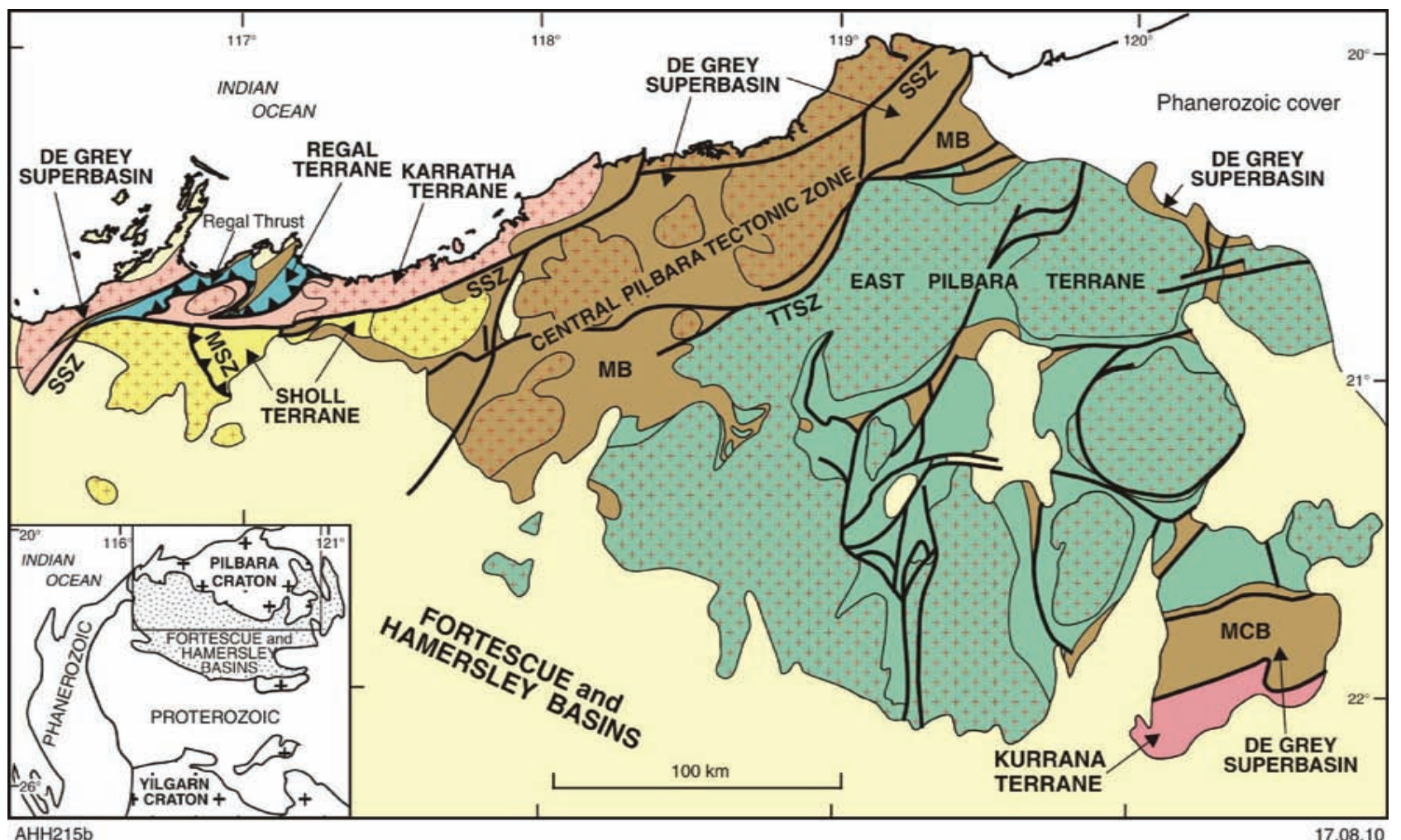

DE GREY SUPERBASIN

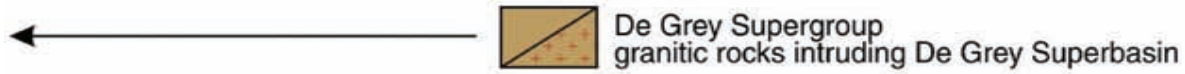

granitic rocks intruding De Grey Superbasin

WEST PILBARA SUPERTERRANE

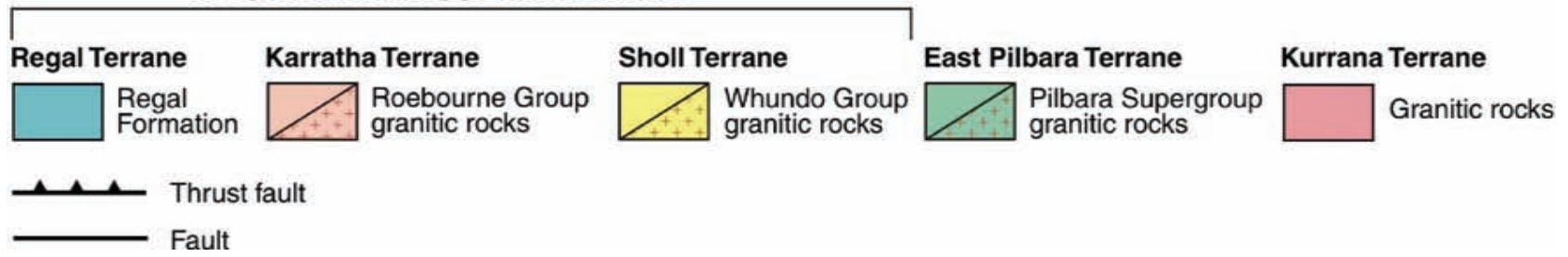

Figure 2 Simplified geology of the northern Pilbara Craton, showing terranes and the De Grey Superbasin. MB, Mallina Basin; MCB, Mosquito Creek Basin; SSZ, Sholl Shear Zone; MSZ, Maitland Shear Zone; TTSZ, Tabba Tabba Shear Zone. 


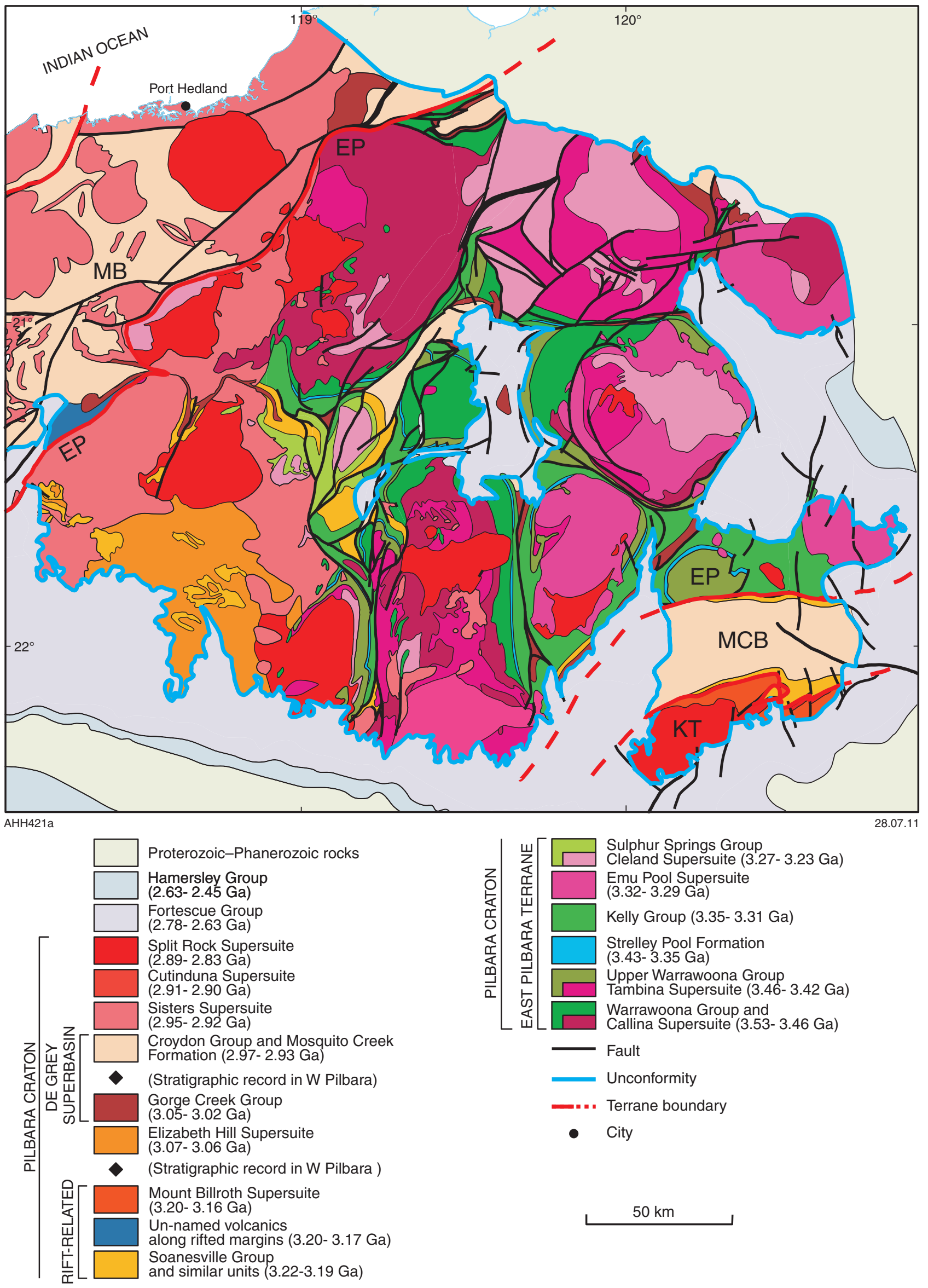

Figure 3 Geology of the East Pilbara Terrane and adjacent tectonic units, showing all greenstone belts except those $W_{\text {of }} 118^{\circ} 45^{\prime} E$. 
granites between 2.89-2.83 Ga (Split Rock Supersuite) the craton remained stable until c. $2.78 \mathrm{Ga}$.

\section{Early crust (3.80-3.53 Ga)}

The Warrawagine Granitic Complex (Figure 1) includes enclaves of 3.66-3.58 Ga biotite tonalite gneiss within younger granodiorite and monzogranite. Farther W, in the Shaw Granitic Complex, xenoliths of $3.58 \mathrm{Ga}$ gabbroic anorthosite (McNaughton et al., 1988) occur within 3.43 Ga granitic rocks. Many Paleoarchean and Mesoarchean siliciclastic formations contain abundant 3.8-3.6 Ga detrital zircons, indicating erosion of crust up to 300 Myr older than the East Pilbara Terrane (Hickman et al., 2010). The pre-3.53 Ga crust or mantle sources for rocks of the East Pilbara Terrane is also supported by Ndisotopic data (Jahn et al., 1981; Gruau et al., 1987; Bickle et al., 1989; Van Kranendonk et al., 2007a, b; Tessalina et al., 2010). Champion and Smithies (2007) provided evidence that most pre-3.3 Ga granites of the Pilbara Craton were sourced through infracrustal melting of material that was older than $3.5 \mathrm{Ga}$.

\section{East Pilbara Terrane (3.53-3.23 Ga)}

The 3.53-3.23 Ga East Pilbara Terrane (Figures 2 and 3) provides the world's most complete record of Paleoarchean crustal evolution. Stratigraphy, structure, geochronology, and geochemistry collectively testify that the evolution of this terrane was dominated by volcanism, magmatic intrusion, and deformation during repeated episodes of heating and melting of underlying older crust (including felsic crust) and mantle over 300 Myr (Van Kranendonk et al., 2002, 2007a, b; Smithies et al., 2005b).

The 3.53-3.23 Ga Pilbara Supergroup of the East Pilbara Terrane is predominantly volcanic (Figure 4) and 15-20 km thick. Thick partial sections of this succession are recognized in almost all greenstone belts of the terrane, except in the NW where younger greenstones are preserved. The three component groups (Warrawoona, Kelly, and Sulphur Springs) of the Pilbara Supergroup are separated by two major erosional unconformities (Figure 4; Buick et al., 1995, 2002; Van Kranendonk et al., 2002). The time gap between the Warrawoona and Kelly groups was c. $75 \mathrm{Myr}(3.427-3.350 \mathrm{Ga})$, and the gap between the Kelly and Sulphur Springs groups was c. 60 Myr (3.315$3.255 \mathrm{Ga}$ ). In both cases, the long pause in volcanic activity was preceded by deformation and metamorphism, and accompanied by subaerial erosion and deposition of clastic sediments. Shallow-water sediments between the Warrawoona and Kelly groups are preserved as the Strelley Pool Formation (up to $1 \mathrm{~km}$ thick; Van Kranendonk, 2010a), whereas siliciclastic rocks of the Leilira Formation (up to 3.9 km thick; Van Kranendonk and Morant, 1998) occur at the base of the Sulphur Springs Group.

Where best preserved, the Pilbara Supergroup is composed of eight ultramafic-mafic-felsic volcanic cycles (Figure 4). Geochronology on the felsic formations of successive cycles, and on contemporaneous granitic intrusions, some of which are subvolcanic (Hickman, 2012), indicates that most of the cycles spanned no more than 10-15 Myr; these cycles are interpreted to have resulted from successive mantle plume events (e.g., Arndt et al., 2001; Van Kranendonk et al., 2007a, b; Smithies et al., 2005b).

A characteristic feature of the terrane is the regional outcrop pattern of granitic domes separated by arcuate belts of volcanosedimentary rocks (greenstones) visible on geological maps
(Figures 1, 2 and 3) and satellite imagery that has been variously described as "dome-and-syncline", "dome-and-basin", or "dome-andkeel" structure. Whereas some previous workers have interpreted this pattern as either the result of cross-folding (e.g., Blewett, 2002) or core complex formation (Zegers et al., 1996; Kloppenburg et al., 2001), neither of these are consistent with the full set of geological and geophysical features of the region (Hickman and Van Kranendonk, 2004). The most widely accepted interpretation is that the dome-andkeel structure arose from punctuated episodes of doming by partial convective overturn of the thick, dense greenstone succession into a partially molten granitic middle crust from 3.46-2.94 Ga (e.g., Hickman, 1975, 1984; Collins et al., 1998; Hickman and Van Kranendonk, 2004; Van Kranendonk et al., 2004, 2007a, b).

Geochemical evidence supporting growth of the East Pilbara Terrane as a thick volcanic plateau has been presented and reviewed in several papers (Smithies et al., 2003, 2005b, 2007a, b; Van Kranendonk et al., 2006, 2007a, b). Detailed mapping, geochronology, and geochemical traverses have established that the 15-20 km thickness of the Pilbara Supergroup is autochthonous and not the result of tectonic duplication by folding or thrusting as proposed by some workers (e.g., Bickle et al., 1980, 1985; Boulter et al., 1987; van Haaften and White, 1998). Smithies et al. (2009) noted that c. $3.52 \mathrm{Ga}$ basalts and andesites, well exposed near the base of the Pilbara Supergroup, are enriched in K, LILE (large-ion lithophile elements), Th, and LREE relative to typical Archean basalt. They concluded that these $3.52 \mathrm{Ga}$ rocks were derived from a mantle source enriched in felsic crustal components by previous episodes of crustal recycling. They also suggested that these $3.52 \mathrm{Ga}$ enriched volcanic rocks, or chemically similar crustal material of similar age, were most likely the source for Paleoarchean tonalite-trondhjemite-granodiorite (TTG) intrusions in the East Pilbara Terrane.

Previous workers have interpreted a variety of tectonic settings for parts of the East Pilbara Terrane, including mid-ocean ridge (Ueno et al., 2001; Komiya et al., 2002; Kato and Nakamura, 2003), oceanic island arc (Komiya et al., 2002) and convergent margins involving continental magmatic arcs above subduction zones (e.g., Bickle et al., 1983, 1993; Barley et al., 1984). However, all of these settings are invalidated by the current data. For example, not only is the thickness of the succession too great for it to represent oceanic crust, but the presence of thick, repeated felsic volcanic and shallow-water sedimentary formations all preclude a mid-ocean ridge origin. Oceanic island arc settings for the felsic volcanic formations are not supported by the geochemical evidence (e.g. Smithies et al., 2007a, b) and geochronological evidence for considerably older (c. 300 Myr. older) crust underlying the Pilbara Supergroup. Interpretations that the felsic volcanics or granitic rocks of the terrane can be explained by convergent margin settings are not supported by regional stratigraphy and structure (Hickman, 2012), or by geochemistry which shows the derivation of contemporaneous felsic volcanic and granitic rocks from the fractionation of tholeiitic parental magmas and from melting across a range of depths within the crust (Van Kranendonk et al., 2007a; Champion and Smithies, 2007; Smithies et al., 2007a, b).

\section{Karratha and Kurrana Terranes (? 3.53-3.16 Ga)}

From 3.23 Ga onwards, the cyclic volcanism of the Pilbara Supergroup ceased, and the crustal evolution of the craton became dominated by Phanerozoic-style plate tectonic processes (Hickman, 2004; Van Kranendonk et al., 2006, 2007a, b, 2010). Crustal extension 


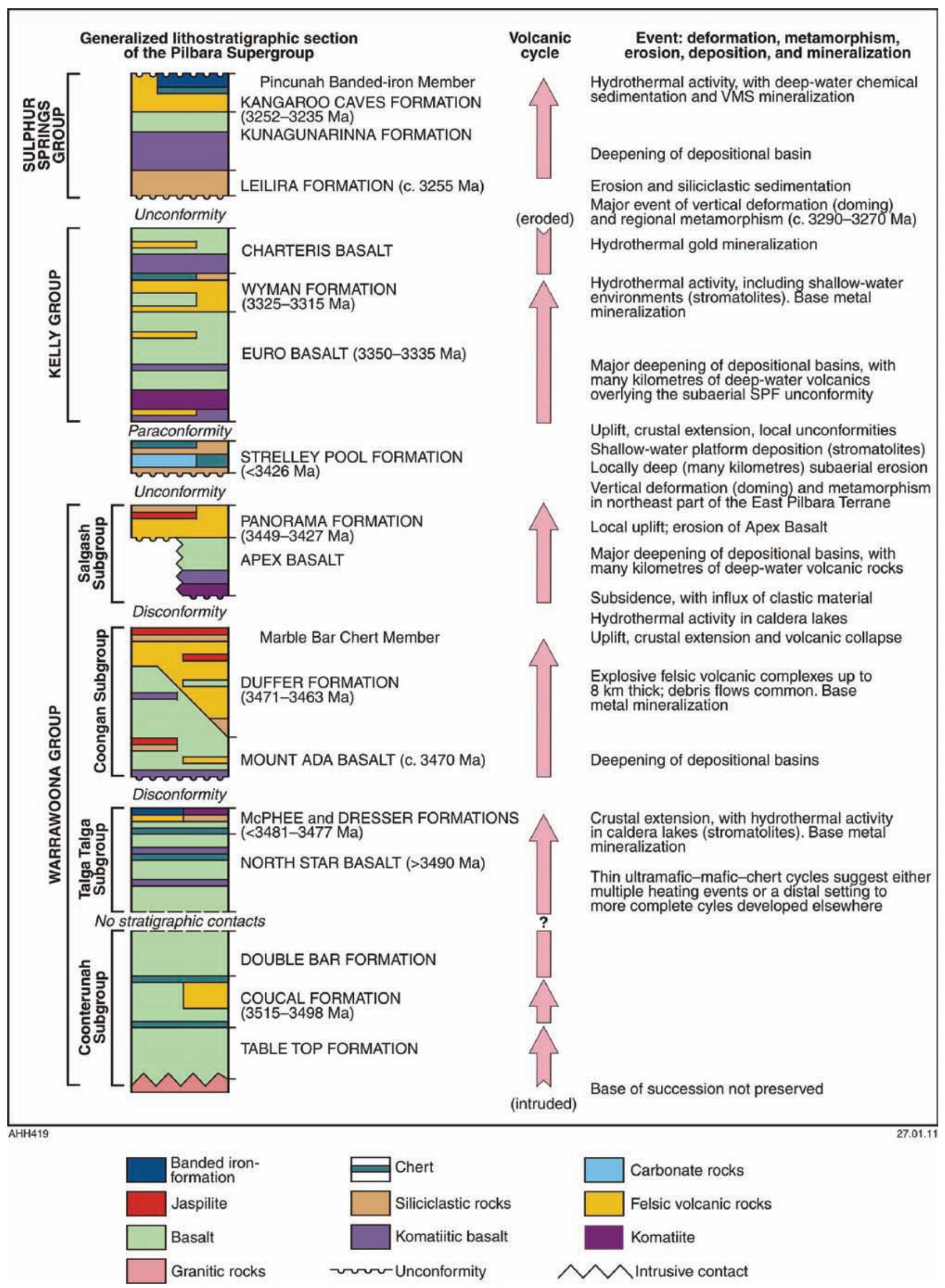

Figure 4 Generalised stratigraphy of the predominantly volcanic Pilbara Supergroup, which is represented in almost all greenstone belts of the East Pilbara Terrane (after Hickman, 2011). 
established two NE-trending zones of rifting and crustal thinning across the East Pilbara Terrane. With continued spreading, these zones developed into rift basins containing c. $3.2 \mathrm{Ga}$ sedimentary and volcanic passive margin successions and oceanic crust. The progenitor to the East Pilbara Terrane became divided into three separate segments of continental crust: a NW microplate, the Karratha Terrane; a remaining central segment of the East Pilbara Terrane; and a SE microplate, the Kurrana Terrane. The Karratha and Kurrana terranes are interpreted to be fragments of the East Pilbara Terrane based on common early histories back to at least $3.45 \mathrm{Ga}$.

The main components of the Karratha Terrane are the undated Ruth Well Formation and the intrusive 3.27-3.26 Ga Karratha Granodiorite (Smith et al., 1998). The Ruth Well Formation is $2 \mathrm{~km}$ thick and consists of metamorphosed ultramafic and mafic volcanic rocks (peridotite to tholeiitic basalt) with a few thin chert intercalations. The overlying Nikol River Formation includes felsic volcaniclastic rocks dated at $3.27-3.25 \mathrm{Ga}$. Nd $\mathrm{T}_{\mathrm{DM}}$ model ages of 3.48-3.43 Ga for the Karratha Granodiorite indicate that magma generation involved older crust or enriched lithospheric mantle (Sun and Hickman, 1998).

In the SE Pilbara, the present exposure of the Kurrana Terrane represents only a small fraction of its total extent, most of which is concealed by the Fortescue and Hamersley basins. Rift-related 3.203.16 Ga granitic rocks of the Mount Billroth Supersuite are widespread in this terrane and intrude undated, strongly deformed supracrustal rocks. Evidence of Paleoarchean crust is provided by xenocrystic zircons ranging in age between $3.58-3.46 \mathrm{Ga}$, and by $\mathrm{Nd} \mathrm{T}_{\mathrm{DM}}$ model ages between 3.45-3.41 Ga (Van Kranendonk et al., 2007b). Mafic and ultramafic sills intruded along the northern boundary of the terrane have not been dated, but are likely to be $3.18 \mathrm{Ga}$ intrusions of the Dalton Suite.

\section{Soanesville Basin, and similar units (3.20- 3.165 Ga)}

Subsidence along the rifted margins of the three separating continental microplates was accompanied by the deposition of shallow-water clastic successions and thick volcanic piles, in passive margin settings. The best preserved succession is that of the Soanesville Group on the NW margin of the East Pilbara Terrane (Figure 3; Van Kranendonk et al., 2006, 2010; Hickman et al., 2010). Similar successions are the Budjan Creek Formation on the SE side of the East Pilbara Terrane, the Coondamar Formation on the NW margin of the Kurrana Terrane, and the Nickol River Formation on the Karratha Terrane (Hickman et al., 2010).

With increasing crustal extension, the rifted margins were intruded by dykes and sills of dolerite, gabbro, and ultramafic rocks of the Dalton Suite (3.18 Ga), and thick pillow basalt was deposited above the clastic sediments (Van Kranendonk et al., 2010). The Dalton Suite also intruded the greenstone belts of the East Pilbara Terrane. Between 3.19 and $3.16 \mathrm{Ga}$ the rifted margins were locally intruded by granitic intrusions of the Mount Billroth Supersuite (Van Kranendonk et al., 2006).

\section{Regal Terrane}

From 3.20 Ga onwards, NW-SE extension between the East Pilbara and Karratha Terranes opened up a basin floored by oceanic crust (Hickman, 2004). Evidence for this basin is mainly geochronological and geochemical (Ohta et al., 1996; Sun and Hickman, 1998; Smithies et al., 2005a, 2007a), because most of it is interpreted to have been destroyed by subduction from 3.13-3.07 $\mathrm{Ga}$. However, the c. $3.2 \mathrm{Ga}$ basaltic Regal Formation is interpreted to be a remnant of this Mesoarchean oceanic crust, forming the Regal Terrane (Figures 2 and 5). The Regal Formation is a $2-3 \mathrm{~km}$-thick sequence of metamorphosed pillow basalt, local basal komatiitic peridotite, and rare chert units that has a lithological composition and geochemistry consistent with oceanic crust (Ohta et al., 1996; Sun and Hickman 1998). The metabasalt has flat REE patterns, $\varepsilon N d$ of c. +3.5 (close to the depleted mantle value (3.2) at $3.20 \mathrm{Ga}$ ), and no geochemical evidence of crustal contamination (Smithies et al., 2007a). The Regal Terrane overlies the Karratha Terrane and the Nickol River Formation above a major zone of horizontal thrusting, the Regal Thrust (Hickman, 2001, 2004; Hickman et al., 2010). The present interpretation is that the Regal Formation was obducted onto the Karratha Terrane at some time between 3.16-3.07 Ga (Hickman, 2004; Hickman et al., 2010).

\section{Sholl Terrane}

The fault-bounded Sholl Terrane (Figures 2 and 5) is composed of volcanic rocks of the 3.13-3.11 Ga Whundo Group, and granitic and mafic rocks of the contemporaneous Railway Supersuite. The Whundo Group is $10 \mathrm{~km}$ thick and consists of a lower volcanic package of calc-alkaline and boninite-like rocks, a middle package of tholeiitic rocks with minor boninite-like rocks and rhyolite, and an upper package of calc-alkaline rocks, including adakite, $\mathrm{Mg}$-rich basalt, Nb-enriched basalt and rhyolite (Smithies et al., 2005a). Sedimentary rocks, which make up less than $1 \%$ of the group, include chert, banded iron formation (BIF), and quartzite. The basal contact of the group is the Maitland Shear Zone, which was originally a lowangle thrust above the Railway Supersuite, and the group is unconformably overlain by the 3.05-3.02 Ga Gorge Creek Group of the De Grey Supergroup (see below).

$\mathrm{Nd}$-isotopic compositions indicate that during its deposition, the Whundo Group was not underlain by crust older than $3.25 \mathrm{Ga}$ (Sun and Hickman, 1998). This evidence, combined with the geochemical features of the group and the fact that it is fault-bounded against crustal remnants with distinct histories, prompted Smithies et al. (2005a) to suggest an intra-oceanic arc origin for the Whundo Group at 3.13 Ga. Previous interpretations as a back arc setting (Krapez and Eisenlohr, 1998; Smith et al., 1998; Smith, 2003) are not supported, due to the lack of evidence for felsic basement, by the presence of boninites, and by low $\mathrm{Th} / \mathrm{La}, \mathrm{La} / \mathrm{Nb}$, and $\mathrm{Ce} / \mathrm{Yb}$ ratios that are more consistent an intra-oceanic arc setting (Smithies et al., 2005a).

\section{West Pilbara Superterrane and Prinsep Orogeny}

At c. $3.1 \mathrm{Ga}$, the Sholl Terrane was isolated from the Karratha and Regal terranes, and all three of these terranes developed separate histories from the East Pilbara Terrane. However, at 3.07 Ga the Sholl and East Pilbara terranes were each intruded by tonalite and granodiorite of the Elizabeth Hills Supersuite (Van Kranendonk et al., 2006). This intrusive event, present in both terranes, was accompanied by recumbent folding, thrusting, and metamorphism along the Regal Thrust, major sinistral strike-slip movement on the Sholl Shear Zone, thrusting of the Whundo Group across the Railway Supersuite, and recumbent folding and thrusting on the NW side of 
the East Pilbara Terrane (Hickman, 2001, 2004; Hickman et al., 2010; Van Kranendonk et al., 2010). This tectonomagmatic event, referred to as the Prinsep Orogeny, marks the accretion of the Karratha, Regal and Sholl terranes to form the West Pilbara Superterrane, and collision of this with the East Pilbara Terrane (Van Kranendonk et al., 2007a, 2010).

\section{De Grey Superbasin}

The De Grey Superbasin unconformably overlies the East Pilbara Terrane and the West Pilbara Superterrane. It is composed of four basins: the Gorge Creek Basin (3.05-3.02 Ga), Whim Creek Basin (3.01-2.99 Ga), Mallina Basin (3.2-2.94 Ga), and the Mosquito Creek Basin (2.99-2.90 Ga).

The regionally extensive Gorge Creek Basin is composed of the Gorge Creek Group, which in most areas consists of basal conglomerate and sandstone overlain by a 1,000 m-thick unit of BIF, chert, and black shale (Cleaverville Formation). Deposition was initially in shallow-water, and included evaporite and fluviatile deposits (Sugitani et al., 1998). Deposition of the group followed widespread erosion after the 3.07 Ga Prinsep Orogeny, and was probably developed in response to post-orogenic crustal relaxation and subsidence.

The 3.01-2.99 Ga Whim Creek Basin is located immediately to the SE of the Sholl Shear Zone and contains the Whim Creek Group of volcanic, intrusive, and volcaniclastic rocks. Reactivation of this shear zone by N-S convergence between 3.01-3.00 Ga resulted in transpressional, tight to isoclinal folding of the Gorge Creek Group and metamorphism of adjacent parts of the Whundo Group, prior to deposition of the Whim Creek Group. The depositional setting of the Whim Creek Group was interpreted as a pull-apart basin by Barley (1987), but Pike and Cas (2002) suggested it formed in an ensialic back-arc basin. Smith (2003) considered that the TTG of the contemporaneous Maitland River Supersuite (3.00-2.98 Ga)

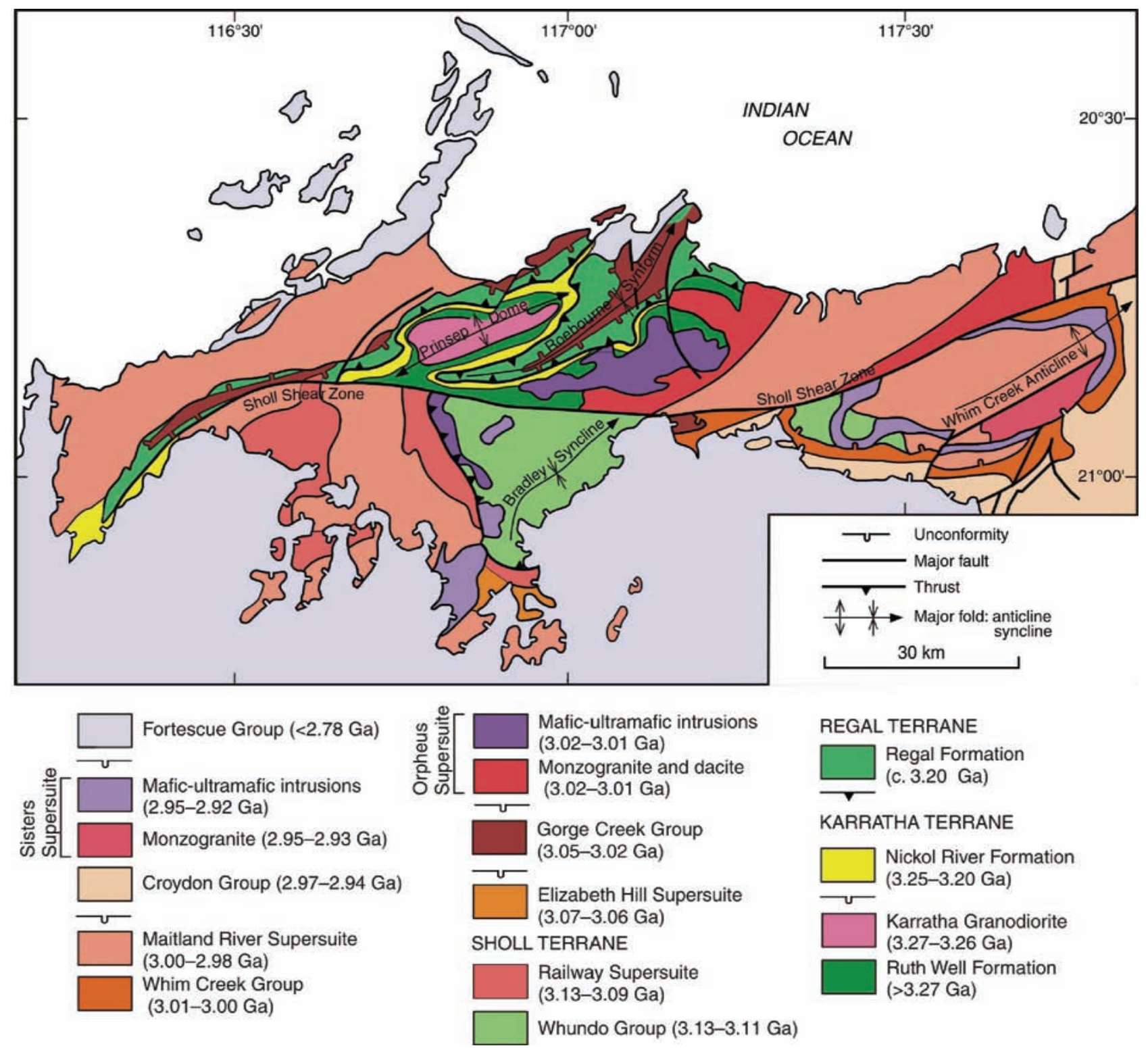

Figure 5 Simplified geology of the NW Pilbara Craton, showing stratigraphy and major structures. The three terranes (Karratha, Regal, and Sholl) are separated by major faults, and each has an entirely different stratigraphy and tectonic history. 
represents the roots of a continental arc, and a subduction origin is supported by the geochemistry of basalt in the group, in particular its enrichment in Th and LREE, which is consistent with an enriched mantle source. However, such mantle enrichment is also present in magmas that later intruded the Mallina Basin, and these have not been related to subduction (Smithies et al. 2004). A withinplate extensional setting was interpreted by Van Kranendonk et al. (2007a).

The 250 x $100 \mathrm{~km}$ Mallina Basin (2.97-2.94 Ga) is filled by metasedimentary rocks of the Croydon Group and overlies the interpreted $3.07 \mathrm{Ga}$ collision zone between the East Pilbara Terrane and the West Pilbara Superterrane. This group comprises the Bookingarra Formation (volcaniclastic and mafic-felsic volcanic rocks) and the Constantine Sandstone and Mallina Formation in the main part of the basin. The Mallina Formation is a $2-4 \mathrm{~km}$ thick succession of conglomerate, sandstone, and shale deposited in submarine fans (Eriksson, 1982). The stratigraphy and structural history of the basin records periods of extension and rift-related deposition of clastic sediments, intrusion of ultramafic-mafic sills, and minor basaltic magmatism, alternating with folding, strike-slip faulting, and thrusting during NW-SE compression. Alkali granites, monzogranites, and high-Mg diorites (sanukitoids) of the Sisters Supersuite intruded the basin between 2.95-2.94 Ga. (Smithies and Champion, 2000).

The Mosquito Creek Basin (Figure 2) originated at c. $3.2 \mathrm{Ga}$ as an ENE-WSW-trending rift basin between the East Pilbara and Kurrana terranes. Juvenile basaltic crust is interpreted to have formed in the centre of the basin, but it was later overlain and concealed by clastic sediments of the Mosquito Creek Formation. Thickness estimates for the complexely folded Mosquito Creek Formation range between 1 and $5 \mathrm{~km}$, and the maximum age of deposition of the formation is approximately $2.98 \mathrm{Ga}$ (Nelson, 2004). Nijman et al. (2010) used sedimentological and structural observations to interpret the basin as a late-stage intramontane basin occupying a synclinal depression between domes of the East Pilbara Terrane. However, the northern and southern margins of the basin are in contact with 3.203.16 Ga intrusive units (Mount Billroth Supersuite and Dalton Suite) that in the NW Pilbara Craton are associated with rifting. Secondly, most detrital zircons in the Mosquito Creek Formation have crystallization ages inconsistent with derivation from the East Pilbara Terrane, suggesting a more distant source, perhaps by longitudinal currents within a large rift basin (Bagas et al., 2004).

\section{North Pilbara and Mosquito Creek orogenies}

Two separate events of deformation and metamorphism affected the NW and SE parts of the Pilbara Craton between 2.95-2.90 Ga. In the NW Pilbara, large-scale NE-trending folds and faults associated with the North Pilbara Orogeny deformed the West Pilbara Superterrane between 2.95 - 2.92 Ga (Hickman, 2001). In the central Pilbara, the Mallina Basin was affected by regional transpression at this time, resulting in upright folding and strike-slip faulting (Krapez and Eisenlohr, 1998). In the central part of the East Pilbara Terrane, complex folding and shear deformation of the Lalla Rookh-Western Shaw structural corridor were formed under NW-SE compression at $2.93 \mathrm{Ga}$ (Van Kranendonk and Collins, 1998; Van Kranendonk, 2008).

In the SE Pilbara, fold-thrust style deformation of the Mosquito Creek Formation at c.2.90 Ga (Huston et al., 2002b) during the Mosquito Creek Orogeny was the final result of N-S closure of the
Mosquito Creek Basin as the Kurrana Terrane was accreted to the East Pilbara Terrane (Van Kranendonk et al., 2007a). Intrusion of monzogranite and lesser amounts of other granitic rocks accompanied both orogenies and, as with the deformation, was older in the NW (Sisters Supersuite, 2.95-2.92 Ga) than in the SE (Cutinduna Supersuite, 2.91-2.90 Ga).

\section{Split Rock Supersuite}

The Split Rock Supersuite consists of highly fractionated, Sn$\mathrm{Ta}-\mathrm{Li}$ bearing, post-orogenic monzogranites that were emplaced in a SE-NW-trending linear belt across the Kurrana and East Pilbara terranes between 2.89-2.83 Ga (Van Kranendonk et al., 2007a). Nd model age data indicate derivation of the Split Rock Supersuite from partial melting of much older granitic crust, commonly with model ages of between 3.7-3.4 Ga (Bickle et al., 1989; Smithies et al., 2003).

\section{Fortescue, Hamersley and Turee Creek basins (2.78-2.42 Ga)}

The Neoarchean-Paleoproterozoic successions of the Fortescue, Hamersley, Turee Creek basins unconformably overlie the Pilbara Craton and record a history that commenced with $2.78 \mathrm{Ga}$ crustal extension and volcanic plateau volcanism (Fortescue Group), through passive margin settings (2.63-2.45 Ga Hamersley Group), to basin deposition ( $<2.45$ to $>2.21 \mathrm{Ga}$, Turee Creek Group), in advance of the Ophthalmian Orogeny ( $>2.21 \mathrm{Ga}$; Figure 6).

\section{Fortescue Basin}

The Fortescue Basin is entirely composed of the Fortescue Group, a $6 \mathrm{~km}$-thick, predominantly volcanic succession that unconformably overlies the Pilbara Craton across $250,000 \mathrm{~km}^{2}$. In the N Pilbara, the Fortescue Group was deposited in four distinct stages spanning 150 Myr: (1) 2.78-2.77 Ga crustal extension, with local rifting and extrusion of basalt through a swarm of N-NE-trending dolerite dykes; (2) 2.77-2.75 Ga folding and faulting accompanied by rapid deposition of fluvial conglomerate and sandstone and lacustrine shale within shallow rift basins; (3) 2.75-2.71 Ga eruption of plumerelated ultramafic-mafic-felsic volcanic cycles (Arndt et al., 2001) separated by volcaniclastic rocks and stromatolitic limestone of the 2.73-2.72 Ga Tumbiana Formation; (4) 2.71-2.63 Ga deposition of the Jeerinah Formation involving a northerly marine transgression with a basal near-shore facies of sandstone and stromatolitic limestone overlain by an off-shore facies of mudstone, carbonate rocks, carbonaceous pyritic shale, and chert (Thorne and Trendall, 2001). In some areas, clastic units up to several hundred metres thick, and possibly also basaltic units up to $2 \mathrm{~km}$ thick, underlie the Mt Roe Basalt of stage 1, and have been assigned to the Bellary Formation and an un-named formation (Van Kranendonk, 2010b). However, in the absence of geochronology, these local basal units could vary considerably in age.

In the SE Pilbara, stages 1 and 2 are not represented due to nondeposition across an elevated area of the underlying Pilbara Craton known as the Yule-Sylvania High (Thorne and Trendall, 2001). In the SW, stages 2 to 4 are in most cases represented by deeper-water facies than in the northern part of the basin. This southerly deepening 

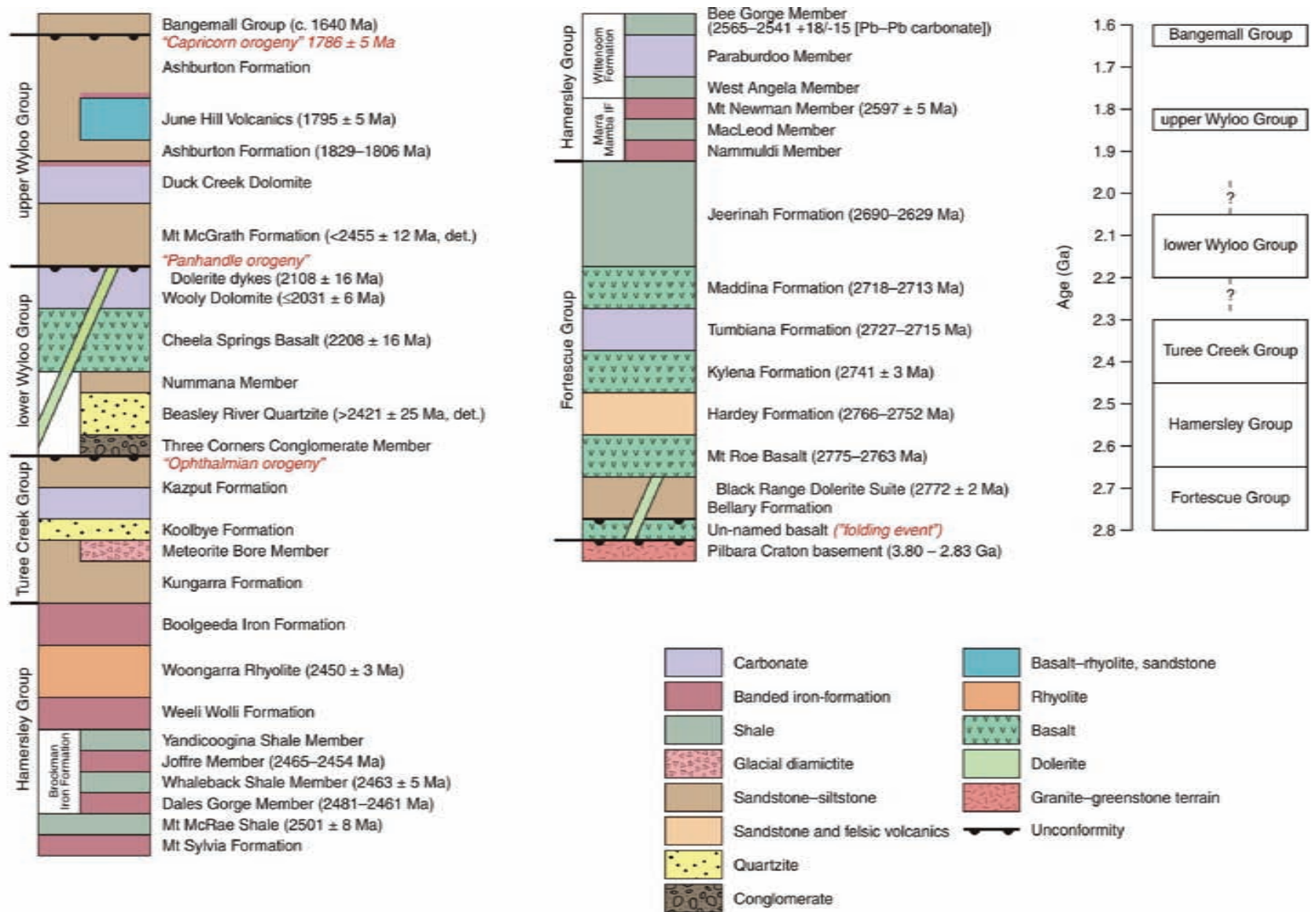

Figure 6 Stratigraphic column of the Neoarchean-Paleoproterozoic succession of the Pilbara region, summarising lithology and geochronological data.

of the Fortescue Basin was accompanied by a marked thickening of the succession in the S, consistent with a major rift axis to the SSW. In the S Pilbara, the Tumbiana Formation of stage 3 is represented by the Pyradie Formation, a $1 \mathrm{~km}$-thick marine unit of komatiite, komatiitic basalt, hyaloclastite, argillite, and chert. In the S Pilbara, the Jeerinah Formation is much thicker than in the N, and consists of 'deeper' shelf deposits, including basalt, as well as being extensively intruded by dolerite sills.

\section{Hamersley Basin}

The Hamersley Basin, which contains the BIF-dominated Hamersley Group (Trendall and Blockley, 1970), overlies most of the southern part of the Pilbara Craton, and its lower stratigraphy is also preserved close to the $\mathrm{E}$ and $\mathrm{W}$ margins of the craton (Figure 1). In the $\mathrm{S}$ and $\mathrm{W}$, the basin stratigraphy represents continuation of the shelf subsidence in stage 4 of the Fortescue Basin, but in the E, deposition was in shallow water and there is no evidence that the central and upper parts of the Hamersley Group were ever deposited here, or across most of the N Pilbara. In the S Pilbara, the Hamersley Group is c. $2.5 \mathrm{~km}$ thick, lies conformably on rocks of the Fortescue Group, and includes four BIF-dominated formations (Marra Mamba, Brockman, and Boolgeeda Iron Formations, and the Weeli Wolli Formation) individually up to $360 \mathrm{~m}$ thick. In most cases, the BIFdominated units are separated by shale, but the carbonate-dominated Wittenoom Formation separates the Marra Mamba and Brockman iron formations. Near the top of the group, the Woongarra Rhyolite has been interpreted by Trendall (1995) as an intrusive, sill-like unit, although it also has obvious extrusive portions.

\section{Turee Creek Basin}

Conformably overlying the Hamersley Basin, close to the southern margin of the Pilbara Craton (Figure 1), the Turee Creek Basin consists largely of greyish-green siltstone, fine-grained greywacke, and finegrained sandstone, but also contains thin-thick carbonate units and glacially-deposited conglomerates and diamictites (Trendall, 1981). Trendall (1979) identified a lower Kungarra Formation, including the Meteorite Bore Member of glacial diamictites that is up to $270 \mathrm{~m}$ thick at the type locality where it consists of diamictite, fine-grained sandstone and shale (Martin, 1999). Detrital zircon dating indicates a maximum depositional age of c. $2.42 \mathrm{Ga}$ (Takehara et al., 2010). The Turee Creek Basin has been interpreted to reflect an accretionary, or collisional, foreland setting in front of the northward-advancing Ophthalmian Fold Belt (Martin and Morris, 2010).

\section{Ashburton Basin}

The Wyloo Group (Figure 6) of the Ashburton Basin consists of low-grade sedimentary and volcanic rocks with a thickness of about $12 \mathrm{~km}$ (Thorne and Seymour, 1991). The group has been divided into unconformity-bound upper and lower parts, the lower part resting unconformably on the Hamersley Basin, and the upper part unconformably overlain by younger Proterozoic basins. 


\section{Lower Wyloo Group}

The lower part of the Wyloo Group consists of the basal Beasley River Quartzite (up to $360 \mathrm{~m}$ thick), which is conformably overlain by the Cheela Springs Basalt and the Wooly Dolomite (Figure 6). This succession lies with marked unconformity on rocks of the Turee Creek and Hamersley basins. The basal Three Corner Conglomerate Member of the Beasley River Quartzite contains abundant clasts of BIF, including pebbles of enriched ore derived from erosion of the Hamersley Group. The $2.21 \mathrm{Ga}$ Cheela Springs Basalt is up to $2 \mathrm{~km}$ thick and consists of basalt derived from a subduction-modified source (Martin and Morris, 2010). The overlying 2.03 Ga Wooly Dolomite is a shallow-marine carbonate succession with locally abundant stromatolites. All of the rocks in the lower Wyloo Group are cut by dolerite dykes emplaced at $2.01 \mathrm{Ga}$.

\section{Upper Wyloo Group}

Deposition of the upper Wyloo Group at 1.83-1.79 Ga included early passive rift deposits, pre- to syn-collisional volcanics (arc?), and younger syn-collisional deposits culminating with the Capricorn Orogeny. The basal Mount McGrath Formation unconformably overlies folded lower Wyloo Group and older rocks, and is composed of upward-fining deltaic and shallow-marine cycles composed of channelized conglomerate and siltstone (Thorne and Seymour, 1991). The conformably overlying Duck Creek Dolomite is up to $1 \mathrm{~km}$ thick and consists of repeated upward-shallowing sequences formed by transgressive and regressive sedimentation on a barred carbonate shoreline (Grey and Thorne, 1985). The formation includes slope, barrier-bar, lagoon, intertidal and supratidal facies, together with major developments of subtidal stromatolitic bioherms. The Duck Creek Dolomite is conformably overlain by relatively deep-water sedimentary and volcanic rocks of the $>5 \mathrm{~km}$-thick, $1.83-1.795 \mathrm{Ga}$, Ashburton Formation.

\section{Archean-Paleoproterozoic biosphere}

Fossil occurrences in the Pilbara region are widespread and preserved in a variety of depositional environments (e.g., Buick and Dunlop, 1990; Brasier et al., 2002; Van Kranendonk, 2007; Hickman, 2012). Within the Pilbara Supergroup, stromatolites, microbial mats, and microfossils have been identified within thin sedimentary units that separate volcanic cycles. The most common habitat was hydrothermal, such as around hot springs or adjacent to hydrothermal vents in settings associated with the waning stages of volcanic activity; such environments were provided by the 3.48 Ga Dresser Formation (Walter et al., 1980; Buick and Dunlop, 1990; Philippot et al., 2007; Van Kranendonk et al., 2008) and the 3.24 Ga Kangaroo Caves Formation (Duck et al., 2007). However, in the case of the Strelley Pool Formation, the growth of stromatolites was prolific in a shallowwater carbonate shelf setting (Hofmann et al., 1999; Allwood et al., 2006). Evidence of Paleoarchean life may also lie in some of the BIF units of the succession because oxidising bacteria or photosynthesising microbiota could have caused BIF deposition through oxidation of dissolved $\mathrm{Fe}^{2+}$ (e.g., Trendall and Blockley, 1970, 2004). The oldest known BIF in the Pilbara Craton is present within the c. $3.52 \mathrm{Ga}$ Coucal Formation.

The Early Mesoarchean successions have so far yielded relatively little evidence of early life. In the passive margin deposits of the $\mathrm{E}$
Pilbara, Duck et al. (2007) identified structures resembling microbial mats near the base of the Soanesville Group. In the W Pilbara, Kiyokawa et al. (2006) reported various structures suggestive of microbial mats and filamentous organic remains from 3.19 Ga oceanic crust at the top of the Regal Formation. In the shallow-water sedimentary rocks at the base of the Late Mesoarchean De Grey Superbasin, microstructures like threads, films, hollow spheres and spindles are interpreted as remnants of microfossils and microbial mats (Sugitani et al. (2009) and within the overlying Cleaverville Formation of the W Pilbara, carbonaceous spheroids occur in black chert (Ueno et al., 2006).

The Neoarchean Fortescue Basin contains widespread stromatolites in lacustrine carbonate units of the Kylena Formation and Tumbiana Formation (Sakurai et al., 2005; Awramik and Buchheim, 2009). Microbial structures within Tumbiana Formation stromatolites were described by Walter (1983) and Lepot et al. (2008). Stromatolites also occur in shallow-water chert at the base of the Jeerinah Formation (Packer and Walter, 1986). Water depths in most formations of the Hamersley Basin were too great for stromatolites, but the shallow-water Carawine Dolomite of the E Pilbara is an exception and is abundantly stromatolitic. The Wooly and Duck Creek Dolomites of the Wyloo Group also contain abundant stromatolites.

\section{Archean-Paleoproterozoic atmosphere}

It is generally accepted that there was a major increase in the $\mathrm{O}_{2}$ content of Earth's atmosphere between 2.4-2.0 Ga (Farquhar et al., 2000), commonly referred to as the 'Great Oxidation Event' (GOE; Holland, 2002). However, some workers have argued either that the atmosphere was oxygenated as early as $4.0 \mathrm{Ga}$ (Ohmoto et al., 2006), or that oxygen increased more gradually or fluctuated from the Paleoarchean to the Paleoproterozoic (e.g., Anbar et al., 2007).

Many workers have used sulfur isotopes to argue that atmospheric oxygen levels were very low prior to the GOE (e.g., Farquhar et al., 2000; Pavlov and Kasting, 2002), based on observations that Archean sedimentary rocks exhibit mass independent fractionation (MIF-S), whereas sedimentary rocks deposited after the GEO do not. Because MIF-S can originate through ultraviolet radiation of volcanic $\mathrm{SO}_{2}$ in the absence of ozone or oxygen, they argued that the MIF-S data provide evidence that Earth's atmosphere changed from anoxic to oxic during the GOE. However, Ohmoto et al. (2005) determined $\delta^{33} \mathrm{~S}$ and $\delta^{34} \mathrm{~S}$ values on bulk-rock $\mathrm{S}$ from the $2.93 \mathrm{Ga}$ Mosquito Creek Formation and reported an absence of MIF-S in all but one of the 40 samples - inconsistent with an Archean anoxic atmosphere. They also obtained the same result when they analysed shale from the 2.76 Ga Hardey Formation. Similarly, Kato et al. (2009) reported hematite pre-dating veins of non-oxidised $2.76 \mathrm{Ga}$ pyrite in drill core through the 3.46-3.45 Ga Apex Basalt, and concluded that the hematite must have been formed by oxygenated groundwater prior to $2.76 \mathrm{Ga}$. Kaufman et al. (2007) analysed S isotopes in organic-rich shale and carbonate in the $2.50 \mathrm{Ga}$ Mt McRae Shale and found evidence for oxygenation of the seawater. Anbar et al. (2007) found enrichment of Mo and Rh in the Mt McRae Shale, indicating oxidation of Archean crustal sulfide minerals.

Kirschvink and Kopp (2008) suggested that major glaciations would have contributed to the atmospheric rise in oxygen because the melting of glacial ice in seawater releases $\mathrm{O}_{2}$ from the photochemically produced $\mathrm{H}_{2} \mathrm{O}_{2}$ in the ice. The oldest evidence of 
glaciation in the Pilbara is provided by the $<2.45$ but $>2.21 \mathrm{Ga}$ Meteorite Bore Member of the Turee Creek Group.

\section{Archean-Paleoproterozoic mineralisation}

\section{Pilbara Craton}

The recognition that the Pilbara Craton is composed of geologically distinct terranes and basins, formed in different tectonic environments, has explained the large variety of mineralisation styles across the craton. Huston et al. (2002b) reviewed mineralisation of the craton within the context of its crustal evolution. Mineralisation in the East Pilbara Terrane occurred during a sequence of magmatic pulses related to mantle plumes, and extended over almost $300 \mathrm{Myr}$. Deposit types associated with these events include: synvolcanic $\mathrm{Cu}-$ $\mathrm{Zn}-\mathrm{Pb}$-barite volcanic-hosted massive sulfide (VHMS) deposits; hydrothermal barite in the form of both quartz-barite veins and sediment-replacement bedded chert-barite deposits; polymetallic and base metal deposits in porphyritic felsic stocks; porphyry $\mathrm{Cu}-\mathrm{Mo}$ mineralisation; and mesothermal Au deposits in shear zones around granitic domes. Several of the Paleoarchean ore deposits are the oldest of their type in the world: hydrothermal barite in the Dresser Formation $(3.48 \mathrm{Ga})$; volcanic-hosted massive sulfides $(\mathrm{Cu}-\mathrm{Pb}-\mathrm{Zn}$, with $20 \%$ barite) in the Duffer Formation (3.465 Ga); polymetallic (Cu-Pb-Zn$\mathrm{Au}-\mathrm{Ag})$ mineralisation in a porphyritic felsic stock $(3.45 \mathrm{Ga})$; porphyry $\mathrm{Cu}-\mathrm{Mo}(3.31 \mathrm{Ga})$; epigenetic lode Au deposits as old as $3.40 \mathrm{Ga}$ (Huston et al., 2002b).

The c. $3.2 \mathrm{Ga}$ rift-related passive margin successions contain little known mineralisation other than Au in the Nickel River Formation. The Au has been mined from shear zones within the Regal Thrust Zone, and it is uncertain if the source of the Au is detrital or hydrothermal. Rift-related ultramafic-mafic intrusions of the Dalton Suite $(3.18 \mathrm{Ga}$ ) contain Ni-Cu mineralisation, but grades are generally $<1 \%$ Ni. The Regal Terrane (oceanic crust) is apparently unmineralised, but the Whundo Group of the Sholl Terrane (3.133.11 Ga volcanic arc succession) locally contains economic VHMS $\mathrm{Cu}-\mathrm{Zn}$ mineralisation.

The De Grey Superbasin contains the most economically important mineralisation in the Pilbara Craton. Iron ore from various deposits within the Gorge Creek Basin (3.05-3.02 Ga) has been mined and exported for almost 50 years. The Croydon Group contains c. .2.95 Ga VHMS and sediment-hosted $\mathrm{Pb}-\mathrm{Zn}$ and $\mathrm{Cu}$ deposits at several localities. These deposits were formed during the early stages of alternating extension and compression in the basin, as were $\mathrm{Ni}-\mathrm{Cu}$ and V-Ti-magnetite deposits in ultramafic-mafic layered intrusions intruded into the basin between 2.95-2.92 Ga. Orogenic vein- and shear-hosted Au deposits were formed during closure of the Mallina Basin at about $2.92 \mathrm{Ga}$ (North Pilbara Orogeny). In the SE Pilbara Craton, the Mosquito Creek Orogeny was accompanied by similar orogenic Au deposits between 2.93-2.90 Ga.

The final period of mineralisation in the Pilbara Craton occurred between 2.89-2.83 Ga with pegmatite-hosted Sn-Ta deposits around the margins of highly fractionated post-orogenic granites of the Split Rock Supersuite. Shear-hosted Au mineralisation occurred at 2.89 $\mathrm{Ga}$ in the Mount York area (NW part of the East Pilbara Terrane).

\section{Fortescue, Hamersley, and Turee Creek basins}

The basal unconformity of Fortescue Basin is locally overlain by conglomerate-hosted Au mineralisation in areas where Neoarchean paleodrainage systems were eroding lode Au deposits in the underlying Pilbara Craton. An important lode Au deposit, Paulsens, has recently been developed in the lower Fortescue Group of the Wyloo Dome (SW Pilbara). Underground mining has reached a depth of $400 \mathrm{~m}$, and current production is approximately $75,000 \mathrm{oz}$ Au per annum. In the NE Pilbara, hydrothermal quartz veins have locally been mined for $\mathrm{Pb}, \mathrm{Ag}$, fluorite, $\mathrm{Cu}$ and $\mathrm{V}$. BIFs of the Hamersley Basin, notably the Brockman and Marra Mamba iron formations, contain some of the world's largest deposits of $\mathrm{Fe}$ ore, owing to enrichment that has locally increased grades to approximately 60\% Fe (Blockley, 1990).

\section{Ashburton Basin}

Since the review of mineralisation in the Ashburton Basin by Thorne and Seymour (1991), significant Au deposits have been mined from quartz veins in the Ashburton Formation. Sener et al. (2005) dated the Mount Olympus deposit at $1.74 \mathrm{Ga}$, and interpreted it to represent orogenic $\mathrm{Au}$ mineralisation. Syngenetic stratiform $\mathrm{Au}-\mathrm{Ag}$ mineralisation in the Ashburton Formation has been interpreted to represent submarine hot-spring deposits (Davy et al., 1991). Other mineralisation in the Ashburton Basin includes $\mathrm{Cu}, \mathrm{Pb}, \mathrm{Zn}$ and $\mathrm{Ag}$ along fault zones.

\section{Acknowledgements}

Alec Trendall and David Champion are thanked for their constructive criticism and advice that resulted in significant improvements to the paper. The authors publish with the permission of the Director of the Geological Survey of Western Australia.

\section{References}

Anbar, A.D., Duan, Y., Lyons, T.W., Arnold, G.L., Kendall, B., Creaser, R.A., Kaufman, A.J., Gordon, G.W., Garvin, J. and Buick, R, 2007, A whiff of oxygen before the great oxidation event? Science, v. 317, pp. 19031906.

Allwood, A.C., Walter, M.R., Kamber, B.S., Marshall, C.P. and Burch, I.W., 2006, Stromatolite reef from the Early Archaean era of Australia: Nature, v. 441, pp. 714-717.

Arndt, N., Bruzak, G. and Reischmann, T., 2001, The oldest continental and oceanic plateaux: geochemistry of basalts and komatiites of the Pilbara Craton Australia, in Ernst, R.E. and Buchan, K.L. (eds), Mantle Plumes: Their Identification Through Time: Geological Society of America, Special Publication 352, pp. 359-387.

Awramik, S.M. and Buchheim, H.P., 2009, A giant Late Archean lake system: the Meentheena Member (Tumbiana Formation; Fortescue Group), Western Australia. Precambrian Research, v. 174, pp. 215-240

Bagas, L., Farrell, T.R. and Nelson, D.R., 2004, The age and provenance of the Mosquito Creek Formation: Geological Survey of Western Australia, Annual Review 2003-04, pp. 62-70.

Barley, M.E. 1987, The Archaean Whim Creek Belt, an ensialic fault-bounded basin in the Pilbara Block, Australia: Precambrian Research, v. 37, pp. 199-215.

Barley, M.E., Sylvester, G.C. and Groves, D.I., 1984, Archaean calc-alkaline volcanism in the Pilbara Block, Western Australia: Precambrian Research, v. 24, pp. 285-319.

Bickle, M.J., Bettenay, L.F., Boulter, C.A., Groves, D.I. and Morant, P., 1980, Horizontal tectonic intercalation of an Archaean gneiss belt and greenstones, Pilbara Block, Western Australia: Geology, v. 8, pp. 525529.

Bickle, M.J., Bettenay, L.F., Barley, M.E., Chapman, H.J, Groves, D.I., Campbell, I.H. and de Laeter, J.R., 1983, A 3500 Ma plutonic and volcanic 
calc-alkaline province in the Archaean East Pilbara Block: Contributions to Mineralogy and Petrology, v. 84, pp. 25-35.

Bickle, M.J., Morant, P., Bettenay, L.F., Boulter, C.A., Blake, T.S. and Groves, D.I., 1985, Archaean tectonics of the Shaw Batholith, Pilbara Block, Western Australia: structural and metamorphic tests of the batholith concept, in Ayers, L.D., Thurston, P.C., Card, K.D. and Weber, W. (eds), Evolution of Archean Supracrustal Sequences: Geological Association of Canada, Special Paper 28, pp. 325-341.

Bickle, M.J., Bettenay, L.F., Chapman, H.J., Groves, D.I., McNaughton, N.J., Campbell, I.H. and de Laeter, J.R., 1989, The age and origin of younger granitic plutons of the Shaw batholith in the Archaean Pilbara Block, Western Australia: Contributions to Mineralogy and Petrology, v. 101, pp. 361-376.

Bickle, M.J., Bettenay, L.F., Chapman, H.J., Groves, D.I., McNaughton, N.J., Campbell, I.H. and de Laeter, J.R., 1993, Origin of the 3500-3300 Ma calc-alkaline rocks in the Pilbara Archaean: isotopic and geochemical constraints from the Shaw Batholith: Precambrian Research, v. 60, pp. $117-149$.

Blewett, R.S., 2002, Archaean tectonic processes: a case for horizontal shortening in the North Pilbara granite-greenstone terrane, Western Australia: Precambrian Research, v. 113, pp. 87-120.

Blockley, J.G., 1990, Iron ore, in Geology and Mineral Resources of Western Australia: Geological Survey of Western Australia, Memoir 3, pp. 679692.

Boulter, C.A., Bickle, M.J., Gibson, B., and Wright, R.K., 1987, Horizontal tectonics pre-dating upper Gorge Creek Group sedimentation, Pilbara Block, Western Australia: Precambrian Research, v. 36, pp. 241-258.

Brasier, M.D., Green, O.R., Jephcoat, A.P., Kleppe, A.K., Van Kranendonk, M.J., Lindsay, J.F., Steele, A., and Grassineau, N., 2002, Questioning the evidence for Earth's oldest fossils: Nature, v. 416, pp. 76-81.

Buick, R. and Dunlop, J., 1990 Evaporitic sediments of early Archaean age from the Warrawoona Group, North Pole, Western Australia: Sedimentology, v. 37, pp. 247-277.

Buick, R., Thornett, J.R., McNaughton, N.J., Smith, J.B., Barley, M.E. and Savage, M., 1995, Record of emergent continental crust $\sim 3.5$ billion years ago in the Pilbara Craton of Australia: Nature, v. 375, pp. 574-577.

Buick, R., Brauhart, C.W., Morant, P., Thornett, J.R., Maniw, J.G., Archibald, N.J., Doepel, M.G., Fletcher, I.R., Pickard, A.L., Smith, J.B., Barley, M.E., McNaughton, N.J., and Groves, D.I., 2002, Geochronology and stratigraphic relationships of the Sulphur Springs Group and Strelley Granite: a temporally distinct igneous province in the Archaean Pilbara Craton, Australia: Precambrian Research, v. 114, pp. 87-120.

Champion, D.C. and Smithies, R.H., 2007, Geochemistry of Paleoarchean granites of the East Pilbara Terrane, Pilbara Craton, Western Australia: implications for early Archaean crustal growth, in Van Kranendonk, M.J, Smithies, R.H. and Bennett, V.C. (eds), Earth's Oldest Rocks, Developments in Precambrian Geology 15: Elsevier, Amsterdam, pp. 369409.

Collins, W.J., Van Kranendonk, M.J., and Teyssier, C., 1998, Partial convective overturn of Archaean crust in the east Pilbara Craton, Western Australia: driving mechanisms and tectonic implications: Journal of Structural Geology, v. 20, pp. 1405-1424.

Davy, R., Clarke, R., Thorne, A.M. and Seymour, D.B., 1991, Geology, mineralization, and origin of the Mount Clement gold and lead prospects, Ashburton Basin: Geological Survey of Western Australia, Report 30, pp. 41-63.

Duck, L.J., Glikson M., Golding, S.D. and Webb, R.E., 2007, Microbial remains and other carbonaceous forms from the $3.24 \mathrm{Ga}$ Sulphur Springs black smoker deposit, Western Australia: Precambrian Research, v. 154, pp. 205-220.

Eriksson, K.A., 1982, Geometry and internal characteristics of Archaean submarine channel deposits, Pilbara Block, Western Australia: Journal of Sedimentary Petrology, v. 52, pp. 383-393.

Farquhar, J., Bao, H. and Thiemens, M., 2000, Atmospheric influence of Earth's earliest sulphur cycle: Science, v. 289, pp. 756-758.

Grey, K. and Thorne, A.M., 1985, Biostratigraphic significance of stromatolites in upward shallowing sequences of the early Proterozoic Duck Creek Dolomite, Western Australia: Precambrian Research, v. 29, pp. 183-206.

Gruau, G., Jahn, B-M., Glikson, A.Y., Davy, R., Hickman, A.H. and Chauvel, C., 1987, Age of the Archean Talga Talga Subgroup, Pilbara Block, Western Australia, and early evolution of the mantle: new Sm/Nd isotopic evidence: Earth and Planetary Science Letters, v. 85, pp. 105-116.

Hickman, A.H., 1975, Precambrian structural geology of part of the Pilbara region: Geological Survey of Western Australia, Annual Report 1974, pp. 68-73.

Hickman, A.H., 1983, Geology of the Pilbara Block and its environs: Geological Survey of Western Australia, Bulletin 127, 268 pp.

Hickman, A.H., 1984, Archaean diapirism in the Pilbara Block, Western Australia, in Kröner, A. and Greiling, R. (eds), Precambrian Tectonics Illustrated: E. Schweizerbarts'che Verlagsbuchhandlung, Stuttgart, pp. 113-127.

Hickman, A.H., 2001, Geology of the Dampier 1:100 000 sheet: Geological Survey of Western Australia, 1:100 000 Geological Series Explanatory Notes, $39 \mathrm{pp}$.

Hickman, A.H., 2004, Two contrasting granite-greenstones terranes in the Pilbara Craton, Australia: evidence for vertical and horizontal tectonic regimes prior to 2900 Ma: Precambrian Research, v. 131, pp. 153-172.

Hickman, A.H., 2011, Pilbara Supergroup of the East Pilbara Terrane, Pilbara Craton: updated lithostratigraphy and comments on the influence of vertical tectonics: Geological Survey of Western Australia, Annual Review 2009-2010, pp. 51-59.

Hickman, A.H., 2012, Review of the Pilbara Craton and Fortescue Basin: crustal evolution providing environments for early life: Island Arc, v. 21, pp. $1-31$.

Hickman, A.H. and Van Kranendonk, M.J., 2004, Diapiric processes in the formation of Archaean continental crust, East Pilbara Granite-Greenstone Terrane, Australia, in Eriksson, P.G., Altermann, W., Nelson, D.R., Mueller, W.U. and O. Catuneau, O. (eds), The Precambrian Earth: Tempos and Events: Elsevier, pp. 54-75.

Hickman, A.H., Huston, D.L., Van Kranendonk, M.J. and Smithies, R.H., 2006, Geology and mineralization of the west Pilbara - a field guide: Geological Survey of Western Australia, Record 2006/17, 50 pp.

Hickman, A.H., Smithies, R.H. and Tyler, I.M., 2010, Evolution of active plate margins: West Pilbara Superterrane, De Grey Superbasin, and the Fortescue and Hamersley Basins - a field guide: Geological Survey of Western Australia, Record 2010/3, 74 pp.

Hofmann, H.J., Grey, K., Hickman, A.H., and Thorpe, R., 1999, Origin of 3.45 Ga coniform stromatolites in the Warrawoona Group, Western Australia: Geological Society of America, Bulletin, v. 111, p. 1256-1262.

Holland, H.D., 2002, Volcanic gases, black smokers, and the great oxidation event: Geochimica et Cosmochimica Acta. v. 66, pp. 3811-3826.

Huston, D.L., Hickman, A.H. and Collins, P.L.F., 2002a, Preface to 'A Special Issue Devoted to the Early to Middle Archean Mineral Deposits of the North Pilbara Terrain, Western Australia': Economic Geology, v. 97, pp. 691-693.

Huston, D.L., Sun, S.-S., Blewett, R., Hickman, A.H., Van Kranendonk, M.J., Phillips, D., Baker, D. and Brauhart, C., 2002b, The timing of mineralisation in the Archaean Pilbara Craton, Western Australia: Economic Geology, v. 97, pp. 733-755.

Jahn, B-M., Glikson, A.Y., Peucat, J.J. and Hickman, A.H., 1981, REE geochemistry and isotopic data of Archean silicic volcanics and granitoids from the Pilbara Block, Western Australia: implications for the early crustal evolution: Geochimica et Cosmochimica Acta, v. 45, pp. 16331652.

Kato, Y. and Nakamura, K., 2003, Origin and global tectonic significance of Early Archean cherts from the Marble Bar greenstone belt, Pilbara Craton, Western Australia: Precambrian Research, v. 125, pp. 191-243.

Kato, Y, Suzuki, K., Nakamura, K., Hickman, A.H., Nedachi, M., Kusakabe, M., Bevacqua, D.C. and Ohmoto, H, 2009, Hematite formation by oxygenated groundwater more than 2.76 billion years ago: Earth and Planetary Science Letters, v. 278, pp. 40-49.

Kaufman, A.J., Johnston, D.J., Farquhar, J., Masterson, A.L., Lyons, T.W., Bates, S., Anbar, A., Arnold, G.L., Garvin, J. and Buick, R., 2007, Late Archean biospheric oxygenation and atmospheric evolution: Science, v. 317 , pp. $1900-1903$.

Kirschvink, J.L. and Kopp, R.E., 2008, Paleoproterozoic ice houses and the evolution of oxygen-mediating enzymes: the case for a late origin of photosystem II: Philosophical Transactions of the Royal Society, v. 363, pp. 2755-2765.

Kiyokawa, S., Ito, T., Ikehara, M. and Katajima, F, 2006, Middle Archean volcano-hydrothermal sequence: bacterial microfossil bearing $3.2 \mathrm{Ga}$ Dixon Island Formation, coastal Pilbara terrane, Australia: Geological Society of America, Bulletin, v. 118, pp. 3-22. 
Kloppenburg, A., White, S.H., and Zegers, T.E., 2001, Structural evolution of the Warrawoona Greenstone Belt and adjoining granitoid complexes, Pilbara Craton, Australia: implications for Archaean tectonic processes: Precambrian Research, v. 112, pp. 107-147.

Komiya, T., Maruyama, S., Hirata, T. and Yurimoto, H., 2002, Petrology and Geochemistry of MORB and OIB in the mid-Archean North Pole Region, Pilbara Craton, Western Australia: Implications for the Composition and Temperature of the Upper Mantle at 3.5 Ga: International Geology Review, v. 44, pp. 988-1016.

Krapez, B. and Eisenlohr, B., 1998, Tectonic settings of Archaean (3325$2775 \mathrm{Ma}$ ) crustal-supracrustal belts in the West Pilbara Block: Precambrian Research, v. 88, pp. 173-205.

Lepot, K., Benzerara, K., Brown, G.E. and Philippot, P., 2008, Microbially influenced formation of 2724-million-year-old stromatolites: Nature Geoscience, v. 1, pp. 118-121.

Martin, D.M., 1999, Depositional setting and implications of Paleoproterozoic glaciomarine sedimentation in the Hamersley Province, Western Australia. Geological Society of America, Bulletin, v. 111, pp. 189-203.

Martin, D.M. and Morris, P.A., 2010, Tectonic setting and regional implications of ca. 2.2 Ga mafic magmatism in the southern Hamersley Province, Western Australia: Australian Journal of Earth Sciences, v. 57, pp. 911-931.

McNaughton, N.J., Green, M.D., Compston, W. and Williams, I.S., 1988, Are anorthositic rocks basement to the Pilbara Craton? Geological Society of Australia, Abstracts 21, pp. 272-273.

Nelson, D.R. 2004, 177131: coarse-grained metasandstone, Lionel Well; Geochronology dataset 529; in Compilation of geochronology data, June 2006 update: Geological Survey of Western Australia.

Nijman, W., Clevis, Q. and de Vries, S.T., 2010, The waning stage of a greenstone belt: The Mesoarchean Mosquito Creek Basin of the East Pilbara, Western Australia: Precambrian Research, v. 180, pp. 251271.

Ohmoto, H., Watanabe, Y. and Ikemi, I., 2005, The absence of mass independent fractionation of sulfur isotopes in Archean sedimentary rocks: An insignificant phenomenon? Geochimica et Cosmochimica Acta, Special Supplement, Abstracts of the 15th Annual V.M. Goldschmidt Conference, Moscow, Idaho, U.S.A., 2005, p. A450.

Ohmoto, H, Watanabe, Y, Ikemi, H, Poulson, SR, and Taylor, B.E., 2006, Sulphur isotope evidence for an oxic Archean atmosphere: Nature, v. 442, pp. 908-911.

Ohta, H., Maruyama, S., Takahashi, E., Watanabe, Y. and Kato, Y., 1996, Field occurrence, geochemistry and petrogenesis of the Archaean MidOceanic Ridge Basalts (AMORBs) of the Cleaverville area, Pilbara Craton, Western Australia: Lithos, v. 37, pp. 199-221.

Packer, B.M. and Walter, M.R., 1986, Late Archean hot-spring deposits, Pilbara Block, Western Australia: $12^{\text {th }}$ International Sedimentological Congress Australia, Abstracts, p. 232.

Pavlov, A.A. and Kasting, J.F., 2002, Mass-independent fraction of sulfur isotopes in Archean sediments: strong evidence for an anoxic Archean atmosphere: Archean sediments: Astrobiology, v. 2, pp. 27-41.

Philippot, P., Van Zuilen, M., Lepot, K., Thomazo, C., Farquhar, J., and Van Kranendonk, M., 2007, Early Archean microorganisms preferred elemental sulphur, not sulphate: Science, v. 317, pp. 1534-1537.

Pike, G. and Cas, R.A.F., 2002, Stratigraphic evolution of Archaean volcanic rock-dominated rift basins from the Whim Creek Belt, west Pilbara Craton, Western Australia, in Altermann, W. and Corcoran, P. (eds), Precambrian Sedimentary Environments: A Modern Approach to Depositional Systems: International Association of Sedimentologists, Special Publication 33, Blackwell Science, Oxford, pp. 213-234.

Sakurai, R., Ito, M., Ueno, Y., Kitajima, K. and Maruyama, S., 2005, Facies architecture and sequence-stratigraphic features of the Tumbiana Formation in the Pilbara Craton, northwestern Australia: implications for depositional environments of oxygenic stromatolites during the late Archean: Precambrian Research, v. 138, pp. 255-273.

Sener, A.K., Young, C., Groves, D.I., Krapez, B. and Fletcher, I.R., 2005, Major orogenic gold episode associated with Cordilleran-style tectonics related to the assembly of Paleoproterozoic Australia? Geology, v. 33, pp. 225-228.

Smith, J.B., 2003, The episodic development of intermediate to silicic volcanoplutonic suites in the Archaean West Pilbara, Australia: Chemical Geology, v. 194 , pp. $275-295$.

Smith, J.B., Barley, M.E., Groves, D.I., Krapez, B., McNaughton, N.J., Bickle,
M.J. and Chapman, H.J., 1998, The Sholl Shear Zone, West Pilbara; evidence for a domain boundary structure from integrated tectonostratigraphic analysis, SHRIMP U-Pb dating and isotopic and geochemical data of granitoids: Precambrian Research, v. 88, pp. 143172 .

Smithies, R.H. and Champion, D.C., 2000, The Archaean high-Mg diorite suite: links to tonalite-trondhjemite-granodiorite magmatism and implications for Early Archaean crustal growth: Journal of Petrology, v. 41, pp. 1653-1671.

Smithies, R.H., Champion, D.C., and Cassidy, K.F., 2003, Formation of Earth's early Archean continental crust: Precambrian Research, v. 127, pp. 89-101.

Smithies, R.H., Champion, D.C., and Sun, S.-S., 2004, Evidence for early LILE-enriched mantle source region: diverse magmas from the c. 2.953.0 Ga Mallina Basin, Pilbara Craton, NW Australia: Journal of Petrology, v. 45 , p. $1515-1537$.

Smithies, R.H., Champion, D.C., Van Kranendonk, M.J., Howard, H.M. and Hickman A.H., 2005a, Modern-style subduction processes in the Mesoarchean: geochemical evidence from the $3.12 \mathrm{Ga}$ Whundo intraoceanic arc: Earth and Planetary Science Letters, v. 231, pp. $221-$ 237.

Smithies, R.H., Van Kranendonk, M.J. and Champion, D.C., 2005b, It started with a plume - early Archaean basaltic proto-continental crust: Earth and Planetary Science Letters, v. 238, pp. 284-297.

Smithies, R.H., Champion, D.C., Van Kranendonk, M.J. and Hickman, A.H., 2007a, Geochemistry of volcanic units of the northern Pilbara Craton: Geological Survey of Western Australia, Report 104, 47 pp.

Smithies, R.H., Champion, D.C. and Van Kranendonk, M.J., 2007b, The oldest well-preserved volcanic rocks on Earth: geochemical clues to the early evolution of the Pilbara Supergroup and implications for the growth of a Paleoarchean continent, in Van Kranendonk, M.J., Smithies, R.H. and Bennett, V.C. (eds), Earth's Oldest Rocks. Developments in Precambrian Geology 15: Elsevier, Amsterdam, pp. 339-367.

Smithies, R.H., Champion, D.C. and Van Kranendonk, M.J., 2009, Formation of Paleoarchean continental crust through infracrustal melting of enriched basalt: Earth and Planetary Science Letters, v. 281, pp. 298-306.

Sugitani, K., Yamamoto, K., Adachi, M., Kawabe, I. and Sugisaki, R., 1998, Archaean cherts derived from chemical, biogenic, and clastic sedimentation in a shallow restricted basin: examples from the Gorge Creek Group in the Pilbara Block: Sedimentology, v. 45, pp. 1045-1062.

Sugitani, K., Grey K., Nagaoka, T., Mimura, K. and Walter, M.R., 2009, Taxonomy and biogenicity of Archaean spheroidal microfossils (ca. 3.0 Ga) from the Mount Goldsworthy-Mount Grant area in the northeastern Pilbara Craton, Western Australia: Precambrian Research, v. 173, pp. $50-59$

Sun, S.-S. and Hickman, A.H., 1998, New Nd-isotopic and geochemical data from the west Pilbara - implications for Archaean crustal accretion and shear zone development: Australian Geological Survey Organisation, Research Newsletter, no. 28, pp. 25-29.

Takehara, M., Komure, M., Kiyokawa, S., Horie, K. and Yokoyama, K., 2010, Detrital zircon SHRIMP U-Pb age of 2.3 Ga diamictites of the Meteorite Bore Member in the south Pilbara, Western Australia. 5th International Archean Symposium, Abstracts Volume: Geological Survey of Western Australia, Record 2010/18, pp. 223-224.

Tessalina, S.G., Bourdon, B., Van Kranendonk, M., Birck, J-L., Philippot, P., 2010, Influence of Hadean crust evident in basalts and cherts from the Pilbara Craton: Nature Geoscience, v. 3, pp. 214-217.

Thorne, A.M. and Seymour, D.B., 1991, Geology of the Ashburton Basin: Geological Survey of Western Australia, Bulletin 139, 141 pp.

Thorne, A.M. and Trendall, A.F., 2001, Geology of the Fortescue Group, Pilbara Craton, Western Australia: Geological Survey of Western Australia, Bulletin 144, 249 pp.

Trendall, A.F., 1979, A revision of the Mount Bruce Supergroup: Geological Survey of Western Australia, Annual Report 1978, pp. 63-71.

Trendall, A.F., 1981, The Lower Proterozoic Meteorite Bore Member, Hamersley Basin, Western Australia, in Hambrey, M.J. and Harland, W.B. (eds), Earth's Pre-Pleistocene glacial record: Cambridge University Press, Cambridge, pp. 555-557.

Trendall, A.F., 1990, Pilbara Craton, Introduction, in Geology and Mineral Resources of Western Australia: Geological Survey of Western Australia, Memoir 3, p. 128.

Trendall, A.F., 1995, The Woongarra Rhyolite - a giant lava-like felsic sheet 
in the Hamersley Basin of Western Australia: Geological Survey of Western Australia, Report 42, 70 pp.

Trendall, A.F. and Blockley, J.G., 1970, The iron formations of the Precambrian Hamersley Group, Western Australia, with special reference to the associated crocidolite: Geological Survey of Western Australia, Bulletin $119,365 \mathrm{pp}$.

Trendall, A.F. and Blockley, J.G., 2004, Precambrian iron-formations, in Eriksson, P.G., Altermann, W., Nelson, D.R., Mueller, W.U. and Catuneanu, O. (eds), The Precambrian Earth: Tempos and events in Precambrian time. Developments in Precambrian Geology 12: Elsevier, Amsterdam, pp. 403-421.

Tyler, I.M. and Hocking, R.M., 2008, Tectonic units of Western Australia, 1:2 500 000: Extract from GeoVIEW.WA Geoscience Database: Geological Survey of Western Australia.

Ueno, Y., Maruyama, S., Isozaki, Y. and Yurimoto, H., 2001, Early Archean (ca. $3.5 \mathrm{Ga}$ ) microfossils and ${ }^{13} \mathrm{C}$-depleted carbonaceous matter in the North Pole area, Western Australia: field occurrence and geochemistry, in Nakashima, S., Maruyama, S., Brack, A. and Windley, B.F. (eds), Geochemistry and the Origin of Life: Universal Academic Press, Tokyo, pp. 203-236.

Ueno, Y., Isozaki, Y. and McNamara, K.J., 2006, Coccoid-like microstructures in a $3.0 \mathrm{Ga}$ chert from Western Australia: International Geology Reviews, v. 48, pp. $78-88$.

van Haaften, W.M., and White, S.H., 1998, Evidence for multiphase deformation in the Archean basal Warrawoona Group in the Marble Bar area, East Pilbara, Western Australia: Precambrian Research v. 88, pp. 53-66.

Van Kranendonk M.J., 2007, A review of the evidence for putative Paleoarchean life in the Pilbara Craton, in Van Kranendonk, M.J., Smithies R.H. and Bennet. V.C. (eds), Earth's Oldest Rocks. Developments in Precambrian Geology 15: Elsevier, Amsterdam, pp. 855-896.

Van Kranendonk M.J., 2008, Structural geology of the central part of the Western Shaw-Lalla Rookh structural corridor, Pilbara Craton, Western Australia: Geological Survey of Western Australia, Report 103, 29 pp.

Van Kranendonk, M.J., 2010a, Geology of the Coongan 1:100 000 sheet: Geological Survey of Western Australia, 1:100 000 Geological Series Explanatory Notes, $67 \mathrm{pp}$.

Van Kranendonk, M.J., 2010b, Three and a half billion years of life on Earth: a transect back into deep time: Geological Survey of Western Australia, Record 2010/21, 93 pp

Van Kranendonk, M.J. and Collins, W.J., 1998, Timing and tectonic significance of Late Archaean, sinistral strike-slip deformation in the Central Pilbara Structural Corridor, Pilbara Craton, Western Australia:

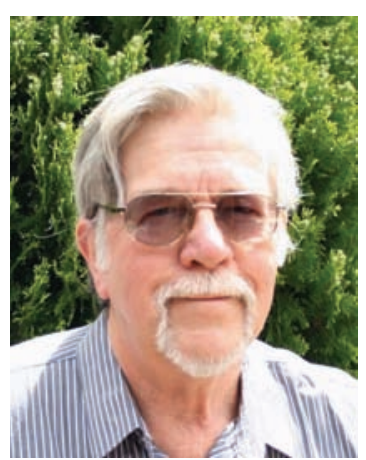

Arthur Hickman's 40-year career with the Geological Survey of Western Australia (GSWA) has included 25 years specifically focused on geological investigation of the Pilbara Craton. From his initial work on the craton in the 1970s, he published new interpretations of the area's Archean stratigraphy and structure, and led several geological excursions to the area. Since 1995, he has been GSWA's leader of the Pilbara Craton Mapping Project, closely collaborating with Geoscience Australia.
Precambrian Research, v. 88, pp. 207-232.

Van Kranendonk, M.J., and Morant, P., 1998, Revised Archaean stratigraphy of the North Shaw 1:100 000 sheet, Pilbara Craton: Geological Survey of Western Australia, Annual Review 1997-98, pp. 55-62.

Van Kranendonk, M.J., Hickman, A.H., Smithies, R.H. and Nelson, D.R., 2002, Geology and tectonic evolution of the Archean North Pilbara Terrain, Pilbara Craton, Western Australia: Economic Geology, v. 97, pp. 695-732.

Van Kranendonk, M.J., Collins, W.J., Hickman, A.H. and Pawley, M.J., 2004, Critical tests of vertical vs horizontal tectonic models for the Archaean East Pilbara Granite-Greenstone Terrane, Pilbara Craton, Western Australia: Precambrian Research, v. 131, pp. 173-211.

Van Kranendonk, M.J., Hickman, A.H., Smithies, R.H., Williams, I.R., Bagas, L. and Farrell T.R., 2006, Revised lithostratigraphy of Archean supracrustal and intrusive rocks in the northern Pilbara Craton Western Australia: Geological Survey of Western Australia, Record 2006/15, $57 \mathrm{pp}$.

Van Kranendonk, M.J., Smithies, R.H., Hickman, A.H. and Champion, D.C., 2007a, Secular tectonic evolution of Archaean continental crust: interplay between horizontal and vertical processes: Terra Nova, v. 19, pp. 1-38.

Van Kranendonk, M.J., Smithies, R.H., Hickman, A.H. and Champion, D.C., 2007b, Paleoarchean Development of a Continental Nucleus: the East Pilbara Terrane of the Pilbara Craton, in Van Kranendonk, M.J., Smithies, R.H. and Bennett, V.C. (eds), Earth's Oldest Rocks. Developments in Precambrian Geology 15: Elsevier, Amsterdam, pp. 307-337.

Van Kranendonk, M.J., Philippot, P., Lepot, K., Bodorkos, S. and Pirajno, F., 2008, Geological setting of Earth's oldest fossils in the ca. 3.5 Ga Dresser Formation, Pilbara Craton, Western Australia: Precambrian Research, v. 167 , pp. $93-124$.

Van Kranendonk, M.J., Smithies, R.H., Hickman, A.H., Wingate, M.T.D. and Bodorkos, S., 2010, Evidence for Mesoarchean ( 3.2 Ga) rifting of the Pilbara Craton: the missing link in an early Precambrian Wilson cycle: Precambrian Research, v. 177, pp. 145-161.

Walter, M.R., 1983, Archean stromatolites: evidence of the Earth's oldest benthos, in Schopf, J.W. (Ed), Earth's earliest biosphere: Princeton University Press, pp. 187-213.

Walter, M.R., Buick, R., and Dunlop, J.S.R., 1980, Stromatolites, 3,4003,500 Myr old from the North Pole area, Western Australia: Nature, v. 284 , pp. $443-445$.

Zegers, T.E., White, S.H., de Keijzer, M. and Dirks, P., 1996, Extensional structures during deposition of the 3460 Ma Warrawoona Group in the eastern Pilbara Craton, Western Australia: Precambrian Research, v. 80, pp. 89-105.

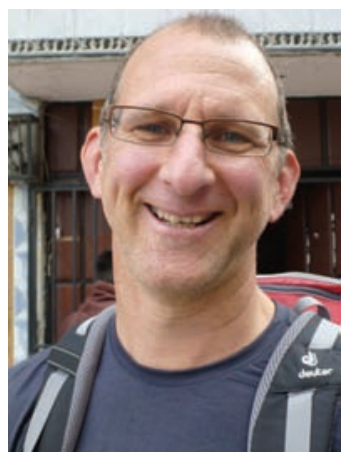

Martin Van Kranendonk is a specialist in Archean geology and the geological setting of the earliest life on Earth. He has collaborated widely with university groups from around the world and is widely published in international journals. He is the Chair of the Precambrian Subdivision of the International Commission on Stratigraphy, associate member of the Australian Centre for Astrobiology, and a coleader of IGCP 599 "The Changing Early Earth", and is an associate editor for Precambrian Research and Episodes. 